\title{
INVESTIMENTO NA FUNÇÃO MASCULINA EM Biomphalaria tenagophila (ORBIGNY) (MOLLUSCA, PLANORBIDAE) AVALIADO PELO NÚMERO DE ESPERMATOZÓIDES
}

\author{
WARTON MONTEIRO ${ }^{1}$ e TOSHIE KAWANO ${ }^{2}$ \\ 'Departamento de Ecologia, Universidade de Brasília, Brasília, DF, Brasil, e-mail: wmonteiro@mma.gov.br \\ ${ }^{2}$ Laboratório de Biologia Celular, Instituto Butantã, Av. Vital Brasil, 1500, CEP 05503-900, São Paulo, SP, Brasil \\ Correspondência para: Toshie Kawano, Av. Vital Brasil, 1500, CEP 05503-900, São Paulo, SP, Brasil \\ Recebido em 10/07/97 - Aceito em 02/06/98 - Distribuído em 28/08/98
}

\begin{abstract}
Investment in male function of Biomphalaria tenagophila (ORBIGNY) (MOLLUSCA, PLANORBIDAE) estimated by spermatozoa numbers
\end{abstract}

\begin{abstract}
Biomphalaria tenagophila is a simultaneous hermaphrodite whose male function investment was estimated by counting spermatozoa from ovotestis and seminal vesicle, under different experimental conditions during the copulation process. As a new technique, spermatozoa were separated in a detergent solution. In all experimental conditions the seminal vesicle contained at least twice as many spermatozoa as the ovotestis to the order of a hundred thousand in ovotestis compared with three or four hundred thousands in the seminal vesicle. There is evidence that the spermatozoa transferred in the copulation process originate from the donnor's seminal vesicle, and the balance of the number of spermatozoa in the seminal vesicle was restored in less than 24 hours.
\end{abstract}

Key words: Biomphalaria tenagophila, mollusca, spermatozoa, numbers, couting.

\section{RESUMO}

Biomphalaria tenagophila é um hermafrodita simultâneo cujo investimento na função masculina foi avaliado pela contagem de espermatozóides do ovoteste e da vesícula seminal, sob diferentes condições experimentais, durante o processo de cópula. Foi criada uma nova técnica para contar espermatozóides separados em uma solução de alquilbenzeno sulfonato de sódio. Em todas as condições experimentais, a vesícula seminal teve mais do dobro de espermatozóides do ovoteste: da ordem de uma centena de milhar para três ou quatro centenas de milhares. Há evidências de que os espermatozóides transferidos no processo de cópula procederam da vesícula seminal do doador e que o equilíbrio do número de espermatozóides na vesícula seminal era restabelecido em menos de 24 horas.

Palavras-chave: Biomphalaria tenagophila, molusco, espermatozóides, número, contagem.

\section{INTRODUÇÃO}

Como os hermafroditas simultâneos em geral, B. tenagophila é dotado de diferentes estratégias reprodutivas (Monteiro \& Dias, 1989). Uma bionfalária inseminada dispõe de, pelo menos, quatro opções de reprodução: 1) fertilizar seus óvulos com os próprios espermatozóides (auto-espermatozóides), isto é, autofecundá-los (Brumpt, 1941); 2) dar preferência aos espermatozóides recebidos do parceiro (aloespermatozóides) para fe- cundar seus próprios óvulos, isto é, praticar fecundação cruzada (Paraense, 1959); 3) transferir parceladamente certas quantidades de seus espermatozóides a um parceiro (Bicalho-Valadares, 1985); 4) partilhar espermatozóides, fertilizando seus óvulos com espermatozóides que seu parceiro recebeu, anteriormente, de outro parceiro (Monteiro et al., 1984).

A estratégia reprodutiva de Biomphalaria parece seguir o modelo de comércio de gametas (Fisher, 1980, 1981; Leonard \& Lukowiak, 1984, 
1985). Segundo o modelo, o comércio de gametas consiste em doar e receber, ou seja, trocar gametas de risco em parcelas alternadas e sucessivas, como forma de minimizar os riscos de perda desses gametas. A transferência de espermatozóides, no caso o gameta de risco, de uma só vez poderia propiciar trapaça por parte do parceiro, que poderia se evadir após receber sua parte, sem retribuir com seus espermatozóides (Leonard \& Lukowiak, 1985). É possível que o parceiro receptor possa usar como nutriente os espermatozóides recebidos.

Essa energia obtida pelo receptor dos espermatozóides pode ser aplicada na formação de óvulos, que podem vir a ser fecundados por um parceiro qualquer. Esse destino frustra o produtor-doador dos espermatozóides, cujo sucesso reprodutivo depende da fecundação de óvulos (Sivinski, 1980). O parcelamento é um modelo que dificulta a trapaça. Ocorre por uma sucessão de pequenas doações que ambos os parceiros fazem, reciprocamente. A alternância dessas doações condiciona o dar para receber (Fischer, 1980). De qualquer forma, o parcelamento e a reciprocidade são meios de minimizar as perdas dos gametas de risco (espermatozóide), que poderiam ser utilizados tanto na fecundação como na nutrição (Monteiro \& Dias, 1989).

O investimento reprodutivo feito pela espécie é uma das variáveis envolvidas na expansão das áreas endêmicas da esquistossomose. Esse investimento pode ser avaliado pelo conhecimento da produção de espermatozóides e pelo número de espermatozóides envolvidos no processo de cópula. Portanto, seu estudo oferece aspectos de ordem teórica e prática. O desenvolvimento das pesquisas nesse sentido tem encontrado dificuldades na separação dos espermatozóides para contagem. Rudolph (1983) contornou a dificuldade, separando parcialmente, mas de modo consistente, os espermatozóides de Bulinus (Physopsis) globosus.

Respeitadas as diferentes condições fisiológicas dos parceiros em B. tenagophila, a alocação de recursos em gametas masculinos representa um papel significativo no comércio de gametas. Os recursos investidos serão estimados pelo processo de ganhos e perdas de espermatozóides. Desta maneira, os objetivos deste trabalho serão: a) estabelecer uma nova técnica para preparar os espermatozóides para contagem; b) estimar o nú- mero de espermatozóides no ovoteste e na vesícula seminal de B. tenagophila, em diferentes condições experimentais, relativas ao processo de cópula.

\section{MATERIAIS E MÉTODOS}

Os caramujos usados nos experimentos foram B. tenagophila, tipo selvagem e mutantes albinos, procedentes de Bom Retiro, em Joinville, $\mathrm{SC}$, mantidos agrupados durante mais de quatro anos, em condições de laboratório. Os aquários foram preparados com $180 \mathrm{ml}$ de água filtrada, saturada com carbonato de cálcio. Na preparação de cada aquário, foi colocada uma colher de sopa de terra avermelhada, esterilizada em estufa seca a $90^{\circ} \mathrm{C}$ durante 12 horas. Os caramujos foram alimentados diariamente com alface fresca e ração duas vezes por semana. Os caramujos usados foram mantidos em isolamento desde a imaturidade sexual.

As análises estatísticas foram feitas pelo programa produto SPSS (Statistical Package for Social Sciences), sobre dados importados do dBase IV - Ashton-Tate Corporation, 1988.

Para separar os espermatozóides, usou-se uma solução de detergente comercial a $10 \%$ : sabão líquido Minerva, da Gessy Lever, cujo ingrediente detergente é o alquilbenzeno sulfonato de sódio. Além de fornecer boa separação, a mistura permanece livre de microrganismos por vários dias.

Os 119 espécimes de B. tenagophila tiveram tanto o ovoteste como a vesícula seminal processados separadamente. Cada peça era dissecada e transportada para um tubo cônico, de aproximadamente $3 \mathrm{ml}$ de capacidade, contendo $1 \mathrm{ml} \mathrm{de}$ solução detergente. Após cerca de uma hora, cada peça era transportada, em pipeta Pasteur com um pouco do líquido detergente, para uma lâmina escavada.

Com o auxílio de dois estiletes, o conteúdo do órgão era expulso por rotura do invólucro e leve compressão sobre folículos, ou divertículos. Com sucessivas adições e retiradas de pequenas quantidades de líquido detergente na lâmina escavada, o material era transportado para o tubo cônico. Em seguida, o líquido era refluxado lentamente com pipeta Pasteur. Pequena fração da mistura era retirada, com a pipeta, para uma câmara Neubauer para contagem dos espermatozóides (Hoy, 1978; Miale, 1967). 
O inconveniente desse procedimento é a perda das cabeças dos espermatozóides na solução detergente. Porém, o número de espermatozóides pode ser obtido contando-se o total de pontas observadas na câmara de Neubauer e dividindose o resultado por dois. De cada amostra foram preparadas cinco lâminas.

Após testes preliminares foram escolhidas cinco condições experimentais:

Grupo 1 (G1) - caramujos mantidos em isolamento desde a imaturidade sexual, a fim de conhecer o número básico de espermatozóides que é mantido no ovoteste e na vesícula seminal. Foram contados espermatozóides de 13 ovotestes e 12 vesículas seminais.

Grupo 2 (G2) - caramujos emparelhados durante 2 a 8 horas e dissecados ao serem separados. Testes preliminares demonstraram que esse período de emparelhamento é suficiente para haver transferência de espermatozóides. Foram contados espermatozóides de 15 ovotestes e 12 vesículas seminais.

Grupo 3 (G3) - caramujos emparelhados durante 4 a 6 horas e dissecados de 17 a 24 horas depois de separados. Foram contados espermatozóides de 19 ovotestes e 19 vesículas seminais.

Grupo 4 (G4) - caramujos emparelhados durante 19 a 31 horas e dissecados ao serem separados. Foram contados espermatozóides de 9 ovotestes e de 10 vesículas seminais.
Grupo 5 (G5) - caramujos emparelhados durante 45 a 168 horas e dissecados ao serem separados. Foram contados espermatozóides de 8 ovotestes e 7 vesículas seminais.

\section{RESULTADOS E DISCUSSÃO}

Uma primeira observação do número de espermatozóides, nos cinco grupos experimentais, G1 a G5, mostra que as médias e medianas da vesícula seminal têm, pelo menos, o dobro dos valores correspondentes do ovoteste (Tabela 1). Mesmo considerando a diferença de metodologia e de espécie estudada, os dados de Rudolph (1983) mostram que o número de espermatozóides produzidos por Bulinus (P.) globosus, após a cópula, é da ordem de centenas de milhares, em concordância com as contagens médias da Tabela 1. Porém, nas espermatecas das rainhas e nas vesículas seminais dos machos de Solenopsis invicta e $S$. richteri (Hymenoptera: Formicidae), o número de espermatozóides é da ordem de unidades de milhões (Glancey \& Lofgren, 1985).

Embora a curta duração do emparelhamento nas condições experimentais de G2 pudesse propiciar a transferência de espermatozóides apenas unidirecionalmente entre os parceiros, o exame das médias dos diferentes grupos não permitiu detectar qual dos parceiros teria agido como doador ou receptor de espermatozóides. Embora haja uma diferença significativa de médias entre alguns dos cinco grupos experimentais, tanto no ovoteste, como na vesícula seminal e na soma dos espermatozóides desses dois órgãos (Tabela 2),

TABELA 1

Número de espermatozóides (x 1000) encontrados no ovoteste e na vesícula seminal e os encontrados no ovoteste somados aos da vesícula seminal de B. tenagophila, com aproximadamente $12 \mathrm{~mm}$ de diâmetro.

\begin{tabular}{|c|c|c|c|c|c|c|c|c|c|c|c|c|c|c|c|}
\hline \multicolumn{6}{|c|}{ Ovoteste (x 1000) } & \multicolumn{5}{|c|}{ Vesícula Seminal (x 1000) } & \multicolumn{5}{|c|}{ Ovoteste + V. Seminal (x 1000) } \\
\hline Grupo & Média & Mediana & Mín. & Máx. & $\mathbf{N}$ & Média & Mediana & Mín. & Máx. & $\mathbf{N}$ & Média & Mediana & Mín & Máx & $\mathbf{N}$ \\
\hline G1 & 162 & 125 & 10 & 725 & 13 & 375 & 380 & 125 & 820 & 12 & 545 & 505 & 265 & 945 & 10 \\
\hline $\mathrm{G} 2$ & 152 & 155 & 0 & 340 & 15 & 386 & 303 & 25 & 1530 & 12 & 580 & 510 & 25 & 1720 & 10 \\
\hline G3 & 162 & 145 & 0 & 350 & 19 & 433 & 430 & 0 & 770 & 19 & 602 & 620 & 0 & 1040 & 18 \\
\hline G4 & 129 & 110 & 30 & 285 & 9 & 353 & 378 & 40 & 690 & 10 & 363 & 418 & 0 & 830 & 8 \\
\hline G5 & 149 & 153 & 70 & 230 & 8 & 367 & 400 & 100 & 580 & 7 & 487 & 495 & 195 & 760 & 6 \\
\hline
\end{tabular}

G1 - caramujos mantidos em isolamento desde a imaturidade sexual; G2 - agrupados aos pares de 2 a 8 horas e dissecados ao serem separados; G3 - agrupados aos pares de 4 a 6 horas e dissecados de 17 a 24 horas depois de separados; G4 - agrupados aos pares de 19 a 31 horas e dissecados ao serem separados; G5 - agrupados aos pares de 45 a 168 horas e dissecados ao serem separados. Máx = valor máximo; Mín = valor mínimo; $\mathrm{N}=$ número de caramujos . 
a identificação de doadores e receptores não é transparente. Isto porque a própria natureza da média não separa, antes ajunta, as frequiências de parceiros doadores com receptores (Tabela 2).

Uma abordagem mais esclarecedora do que a da média é centrada na mediana, uma vez que separa a abscissa em dois campos e sua análise pode salientar a ocorrência de diferentes números de caramujos com frequiências contrastantes, sugerindo tendências correspondentes a parceiros receptores e doadores de espermatozóides. $\mathrm{Ou}$ seja, os receptores tenderão a ter mediana de valor mais elevado do que os doadores. Um teste de medianas revela suas diferenças estatísticas, tanto entre as vesículas seminais como entre os ovotestes (Tabela 3).

Das lâminas preparadas de ovoteste de caramujos isolados (G1), $40 \%$ têm um número de espermatozóides superior ao valor da mediana (Tabela 4). Após o emparelhamento de 2-8 horas de duração (G2), a porcentagem de lâminas com número de espermatozóides superior ao valor da mediana é de $57 \%$.

Essa diferença pode se dever a uma alteração fisiológica que o emparelhamento possa pro- duzir, desencadeando a finalização de espermatogêneses (Rudolph, 1983).

Em experimentos com caramujos isolados (G1) e com 6-8 horas de emparelhamento (G2), havia, respectivamente, $48 \%$ e $33 \%$ de lâminas de vesículas seminais com número de espermatozóides superior ao valor da mediana. Esse resultado de $33 \%$, após curto emparelhamento, pode levar a supor que a transferência dos espermatozóides que estavam na vesícula seminal dos parceiros doadores tenha sido unidirecional, e não foi concluída. O processo de transferência pode ter sido interrompido com a separação dos parceiros para dissecação, cessando o trânsito de gametas ao longo dos dutos condutores do parceiro doador ou do receptor.

No terceiro grupo, com 4-6 horas de emparelhamento e 17-24 horas de isolamento antes da dissecação (Tabela 4), há $61 \%$ de lâminas de vesícula seminal com espermatozóides em número superior ao da mediana. Este é o maior valor relativo encontrado entre as vesículas seminais dos experimentos.

Esse valor pode representar o resultado de uma trapaça involuntária. Pode ser que o tempo

TABELA 2

Teste de Kruskal-Wallis comparando o número de espermatozóides encontrados no ovoteste, na vesícula seminal e nesses dois órgãos tomados em conjunto.

\begin{tabular}{ccccc}
\hline Grupo & Órgão & N & $\begin{array}{c}\text { Estatística de } \\
\text { Kruskal-Wallis }\end{array}$ & Significância \\
\hline G1 a G5 & OT & 313 & 13,26 & 0,01 \\
G1 a G5 & VS & 300 & 16,55 & 0,00 \\
G1 a G5 & OT+VS & 260 & 22,10 & 0,00 \\
\hline
\end{tabular}

G1, G2, G3, G4 e G5 ver Tabela 1. OT = ovoteste; VS = vesícula seminal; OT+VS = soma dos números de espermatozóides do ovoteste e da vesícula seminal; $\mathrm{N}=$ número de lâminas examinadas.

TABELA 3

Teste de Kruskal-Wallis de medianas comparando o número de espermatozóides encontrados no ovoteste e na vesícula seminal.

\begin{tabular}{ccccccc}
\hline Grupo & Órgão & N & Mediana x 1000 & Quiquadrado & GL & P \\
\hline G1 a G5 & VS & 300 & 380 & 11,47 & 4 & 0,02 \\
G1 a G5 & OT & 320 & 140 & 14,64 & 4 & 0,01 \\
\hline
\end{tabular}

G1, G2, G3, G4 e G5 ver Tabela 1. OT = ovoteste; VS = vesícula seminal, $\mathrm{N}$ = número de lâminas examinadas. 
de emparelhamento tenha permitido somente a transferência unidirecional de espermatozóides em vários pares de caramujos. Após a separação dos parceiros do G3, a migração dos espermatozóides pode ter-se completado, ao longo dos dutos, até à vesícula seminal dos parceiros receptores, durante as 17-24 horas de isolamento que precederam a dissecação. Porém, as condições experimentais podem ter interrompido o processo precocemente, antes que os parceiros que atuaram como receptores pudessem retribuir com seus espermatozóides. Este resultado sugere que o processo de cópula, pelo menos virtualmente, possibilita trapaça sob a forma de transferência unidirecional de espermatozóides.

É possível também que, dado o mesmo tempo para a retribuição, como nas condições experimentais dos Grupos 4 e 5 (Tabela 4), nos quais os parceiros permanecem juntos por um tempo relativamente longo, o resultado da cópula seja diverso. No que diz respeito à quantidade de espermatozóides nas vesículas seminais, as taxas ( $48 \%$ e $51 \%$ ) demonstram equilíbrio no número de lâminas examinadas em relação à mediana. Isto sugere que, nas condições naturais, a cópula termine com uma reciprocidade equilibrada de transferência de espermatozóides. O desequilíbrio nos valores dos Grupos 4 e 5, com $29 \%$ e $63 \%$, respectivamente, de caramujos com espermatozóides no ovoteste em número superior à mediana, mostra que o equilíbrio no número de espermatozóides no ovoteste não é tão prontamente res- tabelecido. Isto é, no G4 não houve tempo para a recuperação do equilíbrio no número básico de espermatozóides vistos no G1, enquanto no G5 a espermatogênese ultrapassou o número verificado no G1. O equilíbrio no número de espermatozóides na vesícula seminal pode ser conseguido com aloespermatozóides e, possivelmente, com espermatozóides novos, recém-produzidos.

No ovoteste, mesmo que haja afluxo de aloespermatozóides para o canal coletor, seu estoque deve ser restabelecido, principalmente, à custa de espermatogênese. Uma comparação entre os números de espermatozóides nos Grupos G1 e G5 mostram (Tabela 5) que o equilíbrio do ovoteste deve levar mais tempo para ser atingido do que o da vesícula seminal. Essa disponibilidade dos espermatozóides da vesícula seminal parece evidente.

Em Bulinus (Physopsis) globosus, durante a cópula, a maioria dos espermatozóides armazenados dentro da vesícula seminal é ejaculada (Rudolph, 1983). Em Lymnaea stagnalis, no caramujo que atuou como macho, o número de espermátides e de espermatozóides do ovoteste decrescem do fim da cópula até duas horas depois. O que funcionou como fêmea aumenta o número de espermatozóides duas horas após a cópula (JongBrink de et al., 1985). Neste trabalho, a observação direta da cor e do volume da vesícula seminal durante a dissecação antecipa, grosseiramente, a quantidade de espermatozóides nela contidos. Como conseqüência da cópula, é possível que haja

\section{TABELA 4}

Números de lâminas cujas freqüiências de espermatozóides de B. tenagophila são maiores, iguais ou menores do que o valor da mediana.

\begin{tabular}{ccccccc}
\hline \multirow{2}{*}{ Intervalo } & Órgão & G1 & G2 & $\mathbf{G 3}$ & $\mathbf{G 4}$ & G5 \\
\cline { 3 - 6 } & OT & 26 & 43 & 49 & 13 & 25 \\
GT & & $(40 \%)$ & $(57 \%)$ & $(52 \%)$ & $(29 \%)$ & $(63 \%)$ \\
& OT & 39 & 32 & 46 & 32 & 15 \\
& & $(60 \%)$ & $(43 \%)$ & $(48 \%)$ & $(71 \%)$ & $(37 \%)$ \\
GT & VS & 29 & 20 & 58 & 24 & 18 \\
& & $(48 \%)$ & $(33 \%)$ & $(61 \%)$ & $(48 \%)$ & $(51 \%)$ \\
LE & VS & 31 & 40 & 37 & 26 & 17 \\
& & $(52 \%)$ & $(66 \%)$ & $(39 \%)$ & $(52 \%)$ & $(49 \%)$ \\
\hline
\end{tabular}

Intervalos de frequiências de espermatozóides maiores (GT), iguais ou menores (LE) do que o valor da mediana. G1 (OT: $\mathrm{N}=65$; VS: $\mathrm{N}=60$ ); G2 (OT: $\mathrm{N}=75$; VS: $\mathrm{N}=60$ ); G3 (OT: $\mathrm{N}=95$; VS: $\mathrm{N}=95$ ); G4 (OT: $\mathrm{N}=45$; VS = 50); G5 (OT: $\mathrm{N}=40$; VS = 35); OT = ovoteste; $\mathrm{VS}=$ vesícula seminal; $\mathrm{N}=$ número de $\mathrm{OT}$ ou VS analisado. 
produção de novos espermatozóides e sucessiva transferência dos que estão no ovoteste para recompor o estoque da vesícula seminal.

Alguns desses resultados são ilustrativos para uma série de modelos conhecidos para explicar as estratégias reprodutivas de hermafroditas simultâneos. O primeiro deles é a possibilidade de reciprocidade na transferência de espermatozóides durante a cópula. Isto é, um processo de alternância de papéis de macho e fêmea entre os parceiros (Fischer, 1980, 1981).

$\mathrm{Na}$ economia da reprodução, além do investimento fixo nos órgãos reprodutivos (Heath, 1977), o organismo investe na produção de gametas. Os gametas masculinos e femininos apresentam assimetria de investimento energético, bem como uma assimetria de risco de perda ou destruição no processo reprodutivo. $\mathrm{O}$ sexo que controla a fecundação é aquele que tem assegurado que seus gametas serão usados na formação do zigoto (Leonard \& Lukowiak, 1984). Essas assimetrias são a origem dos conflitos de interesse reprodutivo entre fêmeas e machos dióicos (Trivers, 1972). Os hermafroditas simultâneos reúnem num único indivíduo conflitos de investimento na função masculina e feminina.

$\mathrm{O}$ peixe marinho Hypoplectrus nigrigans (Serranidae) e a lesma marinha Navanax inermis (Opistobranchia), ambos hermafroditas simultâneos, têm como gametas de risco, respectivamente, os femininos e masculinos, e suas estratégias reprodutivas seguem o modelo de comércio de gametas (Fischer, 1980, 1981; Leonard \& Lukowiak, 1984, 1985). O comércio de gametas consiste em doar e receber, ou seja, trocar gametas de risco em parcelas alternadas e sucessivas, como forma de minimizar os riscos de perda desses gametas.
A transferência do gameta de risco de uma única vez poderia propiciar a trapaça por parte de um dos parceiros, que poderia se evadir após receber sua parte sem retribuir com seus gametas de risco (Leonard \& Lukowiak, 1985). É possível que o parceiro receptor possa usar os espermatozóides recebidos como nutrientes. Metabolicamente, o material recebido poderia ser usado como fonte de recurso para a formação de óvulos que poderiam vir a ser fecundados por outro macho, frustrando, assim, o sucesso reprodutivo do primeiro doador (Sivinsk, 1980). O parceiro doador, nesse caso, seria lesado, pois, por seu investimento, nada receberia em troca. $O$ parcelamento pressupõe o recebimento de uma parcela como condição para doar a parcela seguinte (Fischer, 1980).

Não obstante, a transferência parcelada de espermatozóides inclui a possibilidade de perda da primeira parcela, no caso de evasão do parceiro. De qualquer forma, em B. tenagophila e $N$. inermis, o parcelamento e a reciprocidade são meios para minimizar as perdas dos gametas de risco (espermatozóides), que poderiam ser utilizados tanto na fecundação como na nutrição.

Uma indicação de ocorrência de parcelamento de gametas em B. tenagophila está na transferência de espermatozóides em números múltiplos: um mesmo caramujo pode doar, em uma cópula, uma, duas ou três doses de espermatozóides, reveladas pelos números de embriões híbridos produzidos pelos receptores (BicalhoValadares, 1985). Evidentemente, o gameta de risco nas bionfalárias é o espermatozóide, que pode ser armazenado e lisado, ou fagocitado. Os dados da Tabela 4 acrescentam uma possibilidade de B. tenagophila praticar o comércio de espermatozóides, uma vez que emparelhamentos de

TABELA 5

Teste de Mann-Whitney comparando o número de espermatozóides encontrados no ovoteste, na vesícula seminal e na soma dos espermatozóides desses dois órgãos, em dois grupos.

\begin{tabular}{cccccc}
\hline Grupos & Órgão & W & $\mathbf{Z}$ & $\mathbf{P}$ & $\mathbf{N}$ \\
\hline G1 e G5 & OT & 2407 & 1,90 & 0,03 & 105 \\
G1 e G5 & VS & 1751 & $-0,54$ & 0,29 & 95 \\
G1 e G5 & OT+VS & 1112 & 1,02 & 0,15 & 80 \\
\hline
\end{tabular}

G1 e G5 ver Tabela 1. OT = ovoteste; VS = vesícula seminal; OT+VS = ovoteste e vesícula seminal tomados em conjunto; $\mathrm{N}$ = número de lâminas. 
curta duração parecem resultar em transferências unidirecionais de espermatozóides, enquanto emparelhamentos de mais longa duração propiciam transferências recíprocas entre ambos os parceiros, tendendo a um equilíbrio no número final de espermatozóides contidos nas vesículas seminais dos parceiros.

Associada ao comércio de gametas está a partilha de espermatozóides. Na partilha, caramujos do gênero Biomphalaria inseminados transferem aloespermatozóides para um outro parceiro (Monteiro et al., 1984). Nessa transferência, os espermatozóides estão sendo recomercializados. É possível que os caramujos usem os aloespermatozóides nas etapas iniciais de troca para não arriscar os seus auto-espermatozóides em um processo no qual a evasão do parceiro ou o uso de gametas como nutriente é possível.

Pode ocorrer também competição entre os espermatozóides (irmãos) de um mesmo caramujo para fecundar um número limitado de óvulos: competição local por parceiros (local mate competition) (Hamilton, 1967). Essa competição não aumenta o sucesso reprodutivo do caramujo produtor de espermatozóides, pois não aumenta o número de zigotos produzidos. Por outro lado, os filhotes de bionfalárias se dispersam após a eclosão e, em geral, nascem em ambiente rico em perifíton, onde pastam, reduzindo a possibilidade de competição local por recursos (local resource competition) (Clark, 1978) entre irmãos derivados de óvulos do mesmo caramujo.

Conseqüentemente, nesta perspectiva, um maior investimento em óvulos poderia aumentar o sucesso reprodutivo do produtor de óvulos, porque não há competição entre os filhotes e há espermatozóides em número suficiente para fecundar todos os óvulos.

Reforçando os fatores que favorecem a assimetria da alocação de recursos para a parte feminina, a ocorrência de paternidade múltipla (Mulvey \& Vrijenhoek, 1981), a possibilidade de armazanamento de espermatozóides dentro do receptor por aproximadamente seis meses (BicalhoValadares, 1985) e a capacidade de digestão dos espermatozóides sugerem que eles sejam usados também como nutrientes (Boggs \& Gilbert, 1979). Os espermatozóides recebidos podem, portanto, representar uma economia de energia, cujo saldo poderá ser aplicado em investimentos que incluem a produção de mais óvulos. Conseqüente- mente, o número de aloespermatozóides recebidos controlaria o sucesso reprodutivo das bionfalárias, isto é, o número de óvulos produzidos (Boggs \& Gilbert, 1979). Embora este trabalho não ofereça dados sobre o investimento em óvulos, os números de espermatozóides trocados nos emparelhamentos de diferentes durações (Tabela 4) sugerem um processo de troca que resulta em um equilíbrio no número de espermatozóides trocados. Esse processo pode ser interrompido a qualquer momento, significando ganho para um parceiro e perda para o outro. Mas deve haver uma estratégia evolucionariamente estável determinando os balanços dessas relações entre os parceiros.

A estratégia de comércio de gametas origina a questão do controle materno ou paterno da fecundação cruzada. Isto é, em Biomphalaria, ou o parceiro doador, desempenhando o papel de macho, controlaria a quantidade de espermatozóides transferida, ou o parceiro receptor, desempenhando o papel de fêmea, regularia a duração (quantidade) da transferência, ou, ainda, dosaria a quantidade de aloespermatozóides usada na fertilização dos óvulos. Mas, se, por um lado, o parceiro doador poderia impor o uso de seus espermatozóides por cópulas freqüentes, por outro, aquele que funciona como fêmea poderia digerir esses espermatozóides em vez de usá-los na fecundação de seus óvulos. A grande variação morfológica no complexo peniano das bionfalárias (Paraense, 1975), tanto na relação comprimento da bainha do pênis/prepúcio quanto no ponto de inserção da musculatura, sugere uma intensa seleção sexual no controle do destino dos espermatozóides transferidos (Eberhard, 1985). No caso de Biomphalaria, os aloespermatozóides podem ser armazenados e utilizados por até seis meses (Bicalho-Valadares, 1985; Monteiro et al., 1984), demonstrando longa e decidida preferência por parte do receptor, que esgotando o estoque de aloespermatozóides não retorna à autofecundação, mas cessa a oviposição.

Desse modo, a inibição da autofecundação é tão drástica que ultrapassa o tempo máximo de permanência dos aloespermatozóides no receptor. Portanto, é possível que haja um desvio de investimento para a parte feminina, já que o estoque de aloespermatozóides é duradouro, dispensando temporariamente a produção de autoespermatozóides. As durações dos emparelhamentos adotados neste trabalho foram muito curtas para permitir um 
teste da inibição da produção de espermatozóides em caramujos inseminados.

Biomphalaria produz espermatozóides que possibilitam a autofecundação em casos de isolamento dos indivíduos, e comercializa espermatozóides, o que propicia o recebimento de aloespermatozóides para fecundação cruzada e nutrição. Na cópula, o caramujo pode beneficiar-se mais, obtendo espermatozóides para produção e fertilização de seus óvulos, do que pela tranferência de seus espermatozóides na tentativa de fertilizar os óvulos do parceiro, contrariando, assim, o Princípio de Bateman (Bateman, 1948): o sucesso reprodutivo da fêmea é limitado pela capacidade de produzir ovos, ou pela capacidade de criar os filhotes; enquanto no macho o sucesso reprodutivo é limitado pelo número de fêmeas para inseminação.

A contagem de espermatozóides (Tabela 4) possibilita mostrar que $B$. tenagophila recompõe seu estoque de espermatozóides na vesícula seminal, após os emparelhamentos mais prolongados (Grupos 4 e 5). Se se trata de um estoque de auto-espermatozóides, essa recuperação sugere estar sempre pronta a agir como macho, aproximando seu comportamento dos termos do Princípio de Bateman (Bateman, 1948). Se são aloespermatozóides, afasta-se do Princípio (Monteiro et al., 1984). Os resultados deste trabalho não permitem responder a essa questão.

Embora a metodologia aqui usada não leve à possibilidade de confirmação de transferência de espermatozóides em números múltiplos (Bicalho-Valadares, 1985), os resultados apontam para a prática do comércio de gametas (Tabela 4). Além disso, a possibilidade de reciprocidade alternada evoca a inclusão de Biomphalaria no modelo chamado "Dilema do Hermafrodita" (Leonard, 1990). A teoria moderna dos sistemas de acasalamento está baseada na possível existência de um conflito de interesses entre os parceiros sexuais, submetidos a diferentes pressões seletivas ligadas à reprodução pela produção de óvulos ou de espermatozóides.

Embora, em geral, o sucesso reprodutivo nos dois papéis sexuais seja igual (Fisher, 1958), os hermafroditas simultâneos podem ter recompensas diferentes, preferindo agir como macho ou como fêmea (Bateman, 1948; Charnov, 1979, 1982). É claro que a escolha de um papel sexual depende da cooperação do parceiro. Trata-se de um jogo com disputa de interesses iguais. Os parceiros defrontam-se sempre com duas possibilidades. Podem cooperar, ou seja, copular como macho e como fêmea. Mas podem também insistir em copular apenas no papel de sua preferência. Todos os modelos desenvolvidos dentro do Dilema do Hermafrodita estão baseados na Teoria de Jogos, em que há benefícios, prejuízos e empates (Neumann \& Morgenstern, 1943). No Dilema do Hermafrodita, a melhor estratégia é a da reciprocidade, com algumas tentativas de trapaça no intuito de exercer o papel sexual de sua preferência. Mas esse dilema pode ser apresentado em dois modelos.

Pelo Dilema do Prisioneiro, é preferível deixar de copular algumas vezes do que gastar energia copulando no papel que não seja o de sua preferência. Um outro modelo é aplicado a condições de rarefação populacional. No "Game of Chicken", o segundo modelo, é preferível copular no papel que não atenda a seus interesses do que não copular (Leonard, 1990). Mas no caso de haver encontros repetidos entre os parceiros, o modelo do Olho por Olho, Dente por Dente (Tit for tat) (Axelrod \& Hamilton, 1981) indica a possibilidade de evolução de um sistema de cooperação entre egoístas. Sua prática consiste em cooperar no primeiro encontro e, nos encontros subseqüentes, repetir o papel que o parceiro tiver assumido no último encontro (Axelrod \& Hamilton, 1981; Milinski, 1987).

Nas estratégias reprodutivas, as transferências de espermatozóides podem incluir destino diverso da fertilização. Tanto na gametogênese (Joosse et al., 1968) como na oogênese (JongBrink de et al., 1983), é freqüente a absorção de gametas dentro da gônada. O excessivo número de espermatozóides produzidos, como este trabalho mostra ser o caso de B. tenagophila, tem comportado muitas analogias, salientando a desproporção entre a produção e o uso. Para justificar tão grande número de gametas produzidos, três explicações foram propostas.

A primeira, da prodigalidade, acentua que a superprodução custa pouco e mantém uma grande representatividade nos processos que demandam competição entre gametas.

A segunda, da heterogeneidade e seleção, argumenta que somente uma pequena fração dos gametas possui características reprodutivas. $\mathrm{O}$ restante não passa nos testes de qualidade. 
A última, da função extra, sustenta que os gametas têm outros papéis, diferentes da fertilização. Todas essas propostas são defensáveis (Cohen \& Adeghe, 1987).

\section{CONCLUSÕES}

Os espermatozóides do ovoteste e da vesícula seminal são satisfatoriamente preparados para contagem em solução cujo ingrediente detergente é o alquibenzeno sulfonato de sódio. Na vesícula seminal, geralmente é encontrado um número de espermatozóides superior ao dobro daquele do ovoteste. No processo de cópula, há transferência de espermatozóides da vesícula seminal do parceiro doador para o receptor. Após um emparelhamento prolongado, há tendência para um equilíbrio entre os números dos espermatozóides das vesículas seminais dos parceiros. O ovoteste, porém, leva algum tempo a mais para restabelecer o número básico de seus espermatozóides.

Agradecimentos - Coordenação de Aperfeiçoamento de Pessoal de Nível Superior (CAPES) por bolsa concedida.

\section{REFERÊNCIAS BIBLIOGRÁFICAS}

AXELROD, R. \& HAMILTON, W. D., 1981, The evolution of cooperation. Science, 211: 1390-1396.

BATEMAN, A. J., 1948, Intra-sexual selection in Drosophila. Heredity, 2: 349-368.

BICALHO-VALADARES, M. E., 1985. Comprovação genética de um sistema de acasalamento em Biomphalaria tenagophila (Orbigny) (Mollusca, Planorbidae): uma estratégia reprodutiva em hermafroditismo simultâneo. Tese de Mestrado, Universidade de Brasília, DF, 68p.

BOGGS, C. L. \& GILBERT, L. E., 1979, Male contribution to egg production in butterflies: evidence for transfer of nutrients at mating. Science, 206: 83-84.

BRUMPT, E., 1941, Observations biologiques diverses concernant Planorbis (Australorbis) glabratus hôte intermédiaire de Schistosoma mansoni. Annales de Parasitologie, 17: 9-45.

CHARNOV, E. L., 1979, Simultaneous hermaphroditism and sexual selection. Proceedings of the National Academy of Sciences, 76: 2480-2484.

CHARNOV, E. L., 1982, The theory of sex allocation. Princeton, NJ, Princeton University Press, X + 355 p.

CLARK, A. B., 1978, Sex ratio and local resource competition in a prosimian primate. Science, 201: 163-165.

COHEN, J. \& ADEGHE, A. J-H., 1987, The other spermatozoa: fate and functions. In: H. Mohri, (ed.), New Horizons in sperm cell research, Tokyo, Japan Scientific Society Press, pp. 125-134.
EBERHARD, W. G., 1985, Sexual Selection and Animal Genitalia. Cambridge, Harvard University Press, p. 244.

FISCHER, E. A., 1980, The relationship between mating system and simultaneous hermaphroditism in the coral reef fish Hypoplectus nigricans (Serranidae). Animal Behavior, 28: 620-633.

FISCHER, E. A., 1981, Sexual allocation in a simultaneously hermaphroditic coral reef fish. American Naturalist, 117: 64-82.

FISHER, R. A., 1958, The Genetical Theory of Natural Selection. 2 ed., New York, N.Y., Dover Publications, Inc., $291 \mathrm{p}$.

GLANCEY, M. \& LOFGREN, C., 1985, Spermatozoon counts in males and inseminated queens of the imported fire ants, Solenopsis invicta and Solenopsis richteri (Hymenoptera: Formicidae). Florida Entomologist, 68: 162-168.

HAMILTON, W. D., 1967, Extraordinary sex ratios. Science, 156: 477-488.

HEATH, D. J., 1977, Simultaneous hermaphroditism; cost and benefit. Journal of Theorectical Biology, 64: 363-73.

HOY, L., 1978, Biología de la Reprodución Bovina. Editorial Pueblo Y Educación.

JONK-BRINK de, M., BOER, H. H. \& JOOSSE, J., 1983, Mollusca. In: K.G. Adiyodi \& R.G. Adiyodi (eds.), Reproductive Biology of Invertebrates. 1.: Oogenesis, Oviposition, and Oosorption, John Wiley \& Sons Ltd, pp. 297-355.

JONG-BRINK de, M., JAGER, J. C. \& JONG, J. T. L., 1985, Statistical analysis of frequencies and proportions of cytologically classified spermatogenic cells in hermaphroditic snail Lymnaea stagnalis. 2. Effects of copulation. International Journal of Invertebrate Reproduction and Development, 8: 161-168.

JOOSSE, J., BOER, M. H. \& CORNELISSE, C. J., 1968, Gametogenesis and oviposition in Lymnaea stagnalis as influenced by gamma irradiation and hunger. Symposium of the Zoological Society of London, 22: 213-235.

LEONARD, J. L., 1990, The hermaphrodite's dilemma. Journal of Theoretical Biology, 147: 361-372.

LEONARD, J. \& LUKOWIAK, K., 1984, Male-female conflict in a simultaneous hermaphrodite resolved by sperm trading. American Naturalist, 124: 282-286.

LEONARD, J. \& LUKOWIAK, K., 1985, Courtship, copulation, and sperm trading in the sea slug, Navanax inermis (Opistobranchia: Cephalaspidea). Canadian Journal of Zoology, 63: 2719-2729.

MIALE, J. B., 1967, Laboratory Medicine Hematology. Saint Louis, The C.V. Mosby Company, p. 1257.

MILINSKI, M., 1987, Tit for tat in sitcklebacks and the evolution of cooperation. Nature, 325: 433-435.

MONTEIRO, W., ALMEIDA, JR., J. M. G. \& DIAS, B. F. S., 1984, Sperm sharing in Biomphalaria snails: a new behavioural strategy in simultaneous hermaphroditism. Nature, 308: 727-729. 
MONTEIRO, W. \& DIAS, B. F. S., 1989, Estratégias reprodutivas em Biomphalaria (Mollusca, Planorbidae). Ciência e Cultura, 41: 1051-1054.

MULVEY, M. \& VRIJENHOEK, R. C., 1981, Multiple paternity in the hermaphroditic snail Biomphalaria obstructa. Journal of Heredity, 72: 308-312.

NEUMANN, J. von \& MORGENSTERN, O., 1943, Theory of games for economic behavior. Princeton University Press.

PARAENSE, W.L., 1959, One-sided reproductive isolation between geographically remote populations of a planorbid snail. The American Naturalist, 93:93-101.
PARAENSE, W. L., 1975, Estado atual da sistemática dos planorbídeos brasileiros. Arquivos do Museu Nacional, Rio de Janeiro, 55: 105-128.

RUDOLPH, P. H., 1983, Copulatory activity and sperm production in Bulinus (Physopsis) globosus (Gastropoda: Planorbidae). Journal of Molluscan Studies, 49: 125-132.

SIVINSKI, J., 1980, Sexual selection and insect sperm. Florida Entomologist, 63: 99-111.

TRIVERS, R. L., 1972, Parental investment and sexual selection. In: B. Campbell (org.), Sexual selection and descent of man, 1871-1971. Chicago, Aldine, pp. 136-170. 